creasing and equalising the temperature of the air, particularly during the colder winter months.

It thus appears that, during the winter season of 1880.81 , notwithstanding the extreme cold in England and many other places, the tem. perature of San Remo was much above the usual average-in fact, it was a very warm season ; the weather was also very bright and sunny, though less so than the previous season. There was, however, a greater number of rainy days than the average; the rainfall was greater, and the air less dry; but the rainfall was by no means excessive, being scarcely sufficient to meet the wants of the fcountry, and the relative humidity little more than enough to impart that degree of moisture to the air necessary to prevent its becoming somewhat irritating and exciting, as it not unfrequently does in the Kiviera.

It is well known that a considerable fall of temperature takes place in the Riviera at sunset, and hence invalids are always enjoined to return to the house before that hour. The changes which take place before, at, and after sunset are well shown in Table VI.

This table amply demonstrates the necessity for a strict observance of this injanction. It will be noticed that the greatest fall of temperature takes place when the sky is clear and free from cloud; it is then also that the dew falls, and the air becomes most moist. On cloudy days the fall of temperature is much less, and the air much dryer. (See December 16 th and 17 th.)

\section{THE CLIMATE OF THE UNDERCLIFF, ISLE OF} WIGHT, AS A PLACE OF HEALTH-RESORT.*

\section{By J. L. WhITEIIEAD, M.D., Ventnor.}

In the present brief paper which I propose to read, I am anxious to lay before your notice an uninterrupted series of meteorological observations, as regards the Undercliff of the Isle of Wight, during a period of forty years, and to offer a few remarks with respect to its climate, based on such observations and my own personal experience, which now reckons nearly twenty years.

For the statistics themselves, I am indebted to the labour of the late Dr. Martin, and his brother Mr. Martin, a Member of the Royal College of Surgeons, who has been resident at Ventnor since the year 1838 , and to whom I owe much of the material I have to lay before you.

The meteorological observations which I propose to place before you extend over an unbroken space of forty years-viz., from 1840 to 1879 inclusive. They were commenced by the late Dr. Martin soon after his arrival at Ventnor, and his attention was the more particularly directed to such observations, as he was at that time engaged, on behalf of his friend, the late Sir James Clark, in calculating and arranging for him the tables which were subsequently published in his well-known work upon Climate. Dr. Martin procured the best instruments which were to be procured at that period, and eventually, with the kind counsel of his friend Mr. Glaisher, formed an observatory for the arrangement of his instruments, which has subsequently stood the test of comparison with other observations made at the Royal National Consumption Hospital, between Ventnor and St. Lawrence, as likewise with those of the Rev. Clifford Malden at St. Lawrence, at both of which places the Stevenson stand and verified instruments are employed. The result of the separate observations being so closely in accord, serves to demonstrate the reliability of the observations made at Ventnor, carried over so long a period as that previously mentioned.

The Undercliff of the Isle of Wight extends from Bonchurch to Blackgang, a distance of between six and seven miles, with an average breadth of a third of a mile. It has been formed by the subsidence of the land, at some remote period, from the upper-cliff, which rises between 400 and 500 feet above the level of the sea, and backs it for the most part as with a wall. In its descent, the land has fallen into natural terraces, which face the sea, and front nearly due south. The consequence of such an arrangement, with its insular position, has doubtless a marked influence with regard to its climate, obtaining for it a mildness during the winter, as also coolness during the summer, which it otherwise would not possess; the slanting and terraced condition of the land enabling the sun's rays to fall more directly on the surface than they otherwise could do during the winter, while the shade of the upper cliffs affords protection from the dwelling rays of a summer afternoon, and, with the aid of the sea-breeze shutting out the hot north summer winds, renders the atmosphere comparatively cool and pleasant during the warmest feriods of the year, the result being a mild climate during the winter, and an equally cool climate during the

Read in the Section of Public Medicine at the Annual Meeting of the British Medical Association in Ryde, Isle of Wight, August $188 \mathrm{r}$. summer. In proof of the foregoing observations, it is only necessary to point to the great equability of its temperature, as evidenced by the meteorological observations carried over the long period before alluded to.

Sudden transitions from great heat to cold, and extensive range of tem. perature, may be said to be unknown. The mean daily ranges for the respective seasons of winter, spring, summer, autumn, are as follows: winter, $7.10^{\circ}$; spring, $10.6^{\circ}$; summer, $10.24^{\circ}$; autumn, $8.80^{\circ}$

While considering the climate of the Undercliff, reference may also be made to the difference of temperature and rainfall between Ventno and Newport, the chief town in the island, placed near its centre. Mr. Aldridge, to whom this paper is indebted for the following observation, in a communication published by him in April 1872, says: "With regard to the mean daily maximum temperature, the two towns may be said to be fairly equal during the months of February and March, after which Newport has the superiority until October, when Ventnor takes the lead, and maintains it for the remainder of the twelve months. The Newport excess, in May, June, and July, averages about $2.75^{\circ}$, and is more than half a degree on the mean of the whole year. As to the mean daily minimum, Ventnor has the superiority over Newport throughout the entire year, the excess being I. $75^{\circ}$." "With regard to the amount of rain, Ventnor has the drier climate of the two. Taking the whole year, therefore, the climate of Ventnor is rather warmer, much more equable, and considerably drier than that of Newport. The latter fact may probably be accounted for by Newport being placed to the leeward of the range of down stretching from the Needles to Brading; while Ventnor is to the windward of the range of hills in its more immediate vicinity."

In a very recent paper, Mr. Aldridge makes also the following observation. "In illustration of the great superiority of Ventnor to Newport in times of severe nocturnal cold, it may be mentioned that, in October 1873, the minimum temperature was $37^{\circ}$ at Ventnor, and $28.5^{\circ}$ at Newport. The rise of mean temperature in August and com. parative warmth of the autumn and early winter are also noticeable points in the climate of the Undercliff."

The temperature of Ventnor during the spring months, April and May, does not increase in the same proportion as that of Greenwich, and vegetation is never early; but the continuance of warmth into the autumn months is equally marked, a fact which is thus noticed by Mr. Aldridge, who says: "I find the same result (that is, the warmer autumn) revealed in the comparison with Newport; at Ventnor, October is considerably warmer than May; but at Newport and Greenwich, May is considerably warmer than October: a matter of importance to late visitors. Again, November at Newport is $1^{\circ}$ warmer than March, but at Ventnor it is $2.5^{\circ}$."

The soil of the Undercliff is dry, being for the most part composed of chalk, with the upper greensand stone, intermingled at various points with the gault, but the whole mass is much disrupted and broken up. The result is, that the surface soon dries after rain.

While it has a temperature closely resembling, if not identical with, that of Torquay, Ventnor has the advantage of a much less humid atmosphere, and is consequently by no means so relaxing. Taking the rainfall of forty years, it shows a mean of 28.80 inches. But the gradual increase during the several decades is somewhat remarkable. from I 840 to 1849 , the mean was 25.72 inches; 1850 to $1859,28.44$ inches; I 860 to $1869,29,161$ inches; I870 to I879, 31. 109 inches. The rainfall of $1875-6-7-8-9$ was greatly in excess of that usually recorded in previous years, and it is believed the same result was obtained in other localities, and that such excessive rainfall was a very material cause in producing the evil which tended so much to embarrass and distress the agricultural interests. From the nature of the soil before pointed out, the streets and roads soon become dry after rain, and it is a rare circumstance that the weather should be so continuously bad as totally to prevent out-door exercise during some part of the day. There is also another noticeable feature, which is as true now as it was at the period Dr. Martin alluded to the fact in his work on the Undercliff, "that more rain seems to fall during the night than in the day". The circum. stance is frequently matter of common observation, and it has its advantages in affording for the most part greater facilities for out-door exercise.

The Undercliff is full of springs of the purest water, and the watersupply afforded to the town of Ventnor and its immediate neighbourhood by the water-company has every advantage of not only a very pure, but superabundant source.

The prevailing winds are westerly, and, taking the period of forty years, the northerly and easterly winds, as compared with the southerly and westerly, are 5,934 to 8,584 .

In considering the climate of the Undercliff, it is necessary to bear in mind that we are still dealing with that which pertains to all places 
TABle I. Comparative View of Maxima and Minima Temperatures for Fuly $\mathbf{1} 88 \mathbf{1}$.

\begin{tabular}{|c|c|c|c|c|c|c|c|c|c|c|c|c|c|c|c|c|c|c|c|}
\hline \multicolumn{10}{|c|}{ Maxima for July $\mathbf{r} 88 \mathbf{r}$. } & \multicolumn{10}{|c|}{ Minima for July г $88 \mathbf{1}$. } \\
\hline $\begin{array}{l}\text { I88r. } \\
\text { July. }\end{array}$ & 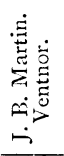 & 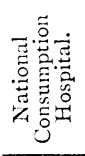 & 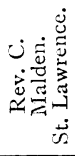 & 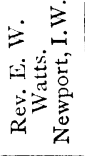 & 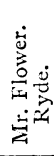 & 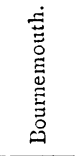 & 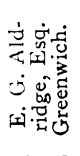 & 悹 & 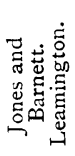 & & 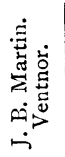 & 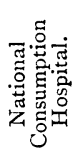 & 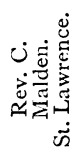 & 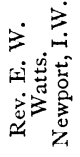 & 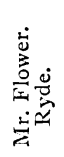 & 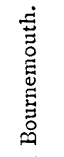 & 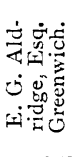 & 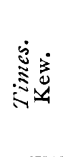 & 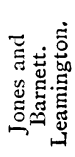 \\
\hline I & 67 & 70.4 & 69.5 & 70.0 & 73 & 69 & 82.6 & 80 & 72.9 & I & 56 & $54 \cdot 2$ & 52.0 & 51.8 & 57 & 50 & 54.6 & 50 & \\
\hline 2 & & & & $74 \cdot 4$ & 75 & 74 & & 74 & & 2 & 54 & & & & & 53 & & 53 & \\
\hline 3 & 68 & 69.0 & 06.0 & & 73 & 77 & 84.7 & 80 & 74.9 & 3 & $5^{8}$ & 58.4 & 57.0 & 50.0 & 59 & $5^{2}$ & & 54 & 56.0 \\
\hline 4 & 73 & $74 \cdot 3$ & $7^{2.0}$ & $8 \mathrm{r} \cdot 3$ & 80 & 78 & 90.1 & 84 & 80.0 & 4 & 58 & $5^{6.9}$ & 56.0 & 56.9 & 59 & & 62 & 52 & 60.7 \\
\hline 5 & 77 & $77 \cdot 4$ & 75.0 & 82.8 & $8 \mathrm{I}$ & 79 & 92.8 & & gr. & 5 & 62 & 57.5 & 57.0 & 54.0 & 65 & 58 & $6 \mathrm{r}$ & 52 & \\
\hline 7 & 60 & 67.0 & 64.5 & 67.2 & 67 & $7^{8}$ & 68.1 & 68 & 67. & 6 & 59 & 57.8 & 58.0 & 58.7 & 62 & $6 \mathrm{r}$ & & 56 & 65.0 \\
\hline $\begin{array}{l}7 \\
8\end{array}$ & 63 & 63.4 & 63.5 & 65.4 & $6 r$ & 68 & $66 . x$ & 67 & 64.9 & 7 & $5^{2}$ & 51.7 & 52.0 & 50.7 & 54 & 50 & & 47 & 2 \\
\hline 9 & 65 & $\begin{array}{l}4.3 \\
66.9\end{array}$ & 63.5 & & 61 & 66 & 65.8 & 65 & 62.8 & 8 & 50 & 53. & 54.0 & 49. & 56 & $5 \mathrm{I}$ & & $5 \mathrm{I}$ & 52.6 \\
\hline $\begin{array}{r}9 \\
\text { 10 }\end{array}$ & 0 & $\begin{array}{l}00.1 \\
68.7\end{array}$ & $\begin{array}{l}65.0 \\
68.0\end{array}$ & 68.3 & 69 & 64 & $7^{2.7}$ & 68 & 70.6 & 9 & 52 & 50.1 & 49.0 & 40.0 & 54 & 44 & & 47 & $49 \cdot 1$ \\
\hline II & 60 & 08.7 & 68.0 & $7 \mathrm{I} \cdot 3$ & $7 \mathrm{I}$ & $7 \mathrm{I}$ & $74 \cdot \mathrm{I}$ & 73 & $7 \mathrm{r} .8$ & ro & 56 & 54.7 & 55.5 & 54.6 & 57 & 53 & & 3 & 52.0 \\
\hline 12 & 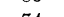 & 71.3 & 08.0 & 75.4 & 73 & 74 & 79.6 & $7^{8}$ & 79.8 & II & $5^{6}$ & 54. & 55.0 & 52.9 & $5^{8}$ & 55 & & 52 & 55.9 \\
\hline$x_{3}$ & 74 & $7^{2.2}$ & 74.0 & 78.9 & 70 & 70 & 86.2 & 79 & 77 . & 12 & 60 & 59.2 & $5^{8.0}$ & 54.5 & 62 & $5^{2}$ & & 52 & \\
\hline $\begin{array}{l}3 \\
x_{4}\end{array}$ & 22 & $\begin{array}{l}75.3 \\
-75.8\end{array}$ & 72.0 & 74.5 & 75 & 79 & $8 \mathrm{r} .4$ & 77 & 75.9 & 13 & 54 & $53 \cdot 3$ & 52.0 & & $5^{8}$ & 52 & 52 & $5 \mathrm{I}$ & \\
\hline $\begin{array}{l}4 \\
\times 5 \\
\end{array}$ & 7.6 & & & 80.1 & 79 & 79 & 89. I & 86 & & $I_{4}$ & 60 & 58.0 & 57.0 & 52.7 & 63 & 56 & & 57 & 62.1 \\
\hline $\begin{array}{l}16 \\
16\end{array}$ & 70 & 80.9 & 70 & 90.4 & (5) & 74 & 97 & $9^{\circ}$ & 87 & ${ } 5$ & 65 & 6r.8 & 62.0 & 55 & 65 & 56 & & 58 & 0 \\
\hline 17 & 77 & 81.9 & & $0.4 \cdot 4$ & 03 & 79 & 84.3 & 81 & $75 \cdot 3$ & 16 & 64 & 63.5 & 63.0 & & 66 & 60 & & $5^{8}$ & 58.9 \\
\hline $\begin{array}{l}1 \\
18\end{array}$ & $7+$ & . & & 02.2 & 79 & 82 & 85.2 & 82 & & 17 & 59 & & 58.0 & 53. & 65 & $5^{6}$ & 61. & 56 & 52.0 \\
\hline 19 & $1+$ & 73.9 & 74.0 & 79.0 & & 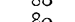 & 90.2 & 87 & 84 & I 8 & 62 & 58.4 & 57.0 & 52.5 & 64 & 53 & & 55 & 57.9 \\
\hline & 77 & & & 05.7 & & $\infty 0$ & 88.0 & 85 & $8 \mathrm{r} .8$ & If & 65 & 64.0 & 63.0 & 57 & 68 & $5^{8}$ & 60.I & $5^{5}$ & 62.7 \\
\hline & 70 & 6 & 6.0 & $74 \cdot 7$ & $7^{2}$ & 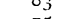 & 76.0 & 73 & & 20 & 60 & 54 & 59.0 & & 64 & 57 & & $5^{6}$ & 53.8 \\
\hline $\begin{array}{l}21 \\
22\end{array}$ & 69 & & 9.0 & 71.9 & 6 & 75 & 73.4 & 72 & & $2 I$ & 53 & 57. & 52.0 & 47. & $5^{8}$ & 50 & & $4^{8}$ & 48.9 \\
\hline & 0.2 & & & 04.9 & 0,3 & & 63.1 & 62 & & 22 & 53 & $53 \cdot 4$ & $5 \mathrm{II.0}$ & & 57 & 50 & 52.0 & $5 \mathrm{I}$ & 52.9 \\
\hline & & & & & & & 73.6 & 70 & & 23 & $5^{8}$ & $57 \cdot 4$ & 57.6 & 56. & 50 & 56 & & 53 & 51.8 \\
\hline 24 & 65 & 66.8 & 65 & 69.6 & 69 & 73 & & 71 & & 24 & 60 & & $5^{8.9}$ & 59. & 62 & 6o & 56.5 & 53 & 66.6 \\
\hline 25 & 62 & 64.9 & 62.3 & 64.8 & 64 & 73 & $7 \times .3$ & 65 & 65 & 25 & 55 & 54. & & & $5^{8}$ & 53 & 5 & 50 & 49.9 \\
\hline 26 & $6_{3}$ & 62.7 & 65.7 & 68.1 & 67 & 66 & & 67 & 67 & 26 & 52 & 50.6 & 55.8 & $5 \mathrm{I}$ & 56 & $5 \mathrm{r}$ & & 50 & 0.1 \\
\hline 27 & 67 & 65.0 & 67 & 69.9 & 66 & 69 & 65.1 & 69 & & 27 & 54 & 52.9 & 52.5 & 53.0 & 57 & $5^{2}$ & 48.5 & 49 & 51.6 \\
\hline 28 & 65 & 67.8 & 66 & 69.2 & 69 & $7 \mathrm{x}$ & 75.9 & 72 & & 28 & 50 & 5 Г. 5 & $49 \cdot 4$ & 37 & 54 & $4 \mathrm{I}$ & 43.9 & 42 & 43.0 \\
\hline 29 & 67 & 70.2 & 66.6 & 69.7 & 70 & $7 \mathrm{x}$ & & 6 & 68 & 29 & $5^{8}$ & $57 \cdot 4$ & 57.2 & & 60 & 58 & 55.6 & 53 & $5^{6.5}$ \\
\hline 30 & 64 & 66.8 & 64.0 & 65.4 & $6_{7}$ & 74 & $68 . x$ & 67 & 65.1 & $30^{\circ}$ & 58 & 56.4 & 56.5 & & $6 \mathrm{x}$ & 59 & 55.5 & $5^{6}$ & 56.9 \\
\hline $3^{I}$ & $6_{4}$ & 63.5 & 64.0 & 65.6 & 05 & 69 & - & 66 & $7^{1} .2$ & $3 \mathrm{r}$ & 59 & 58.2 & 58.0 & 58.8 & $6 \mathbf{x}$ & $5^{6}$ & - & 54 & $56 \cdot 3$ \\
\hline Mean & 68.67 & 70.82 & 68.78 & 73.24 & 72.06 & 73.54 & 74.80 & 74.80 & 73.25 & Mean & 57.16 & 56.04 & 55.87 & 42.72 & 59.93 & 53.70 & 54.88 & 53.12 & 54.89 \\
\hline
\end{tabular}

TABLE II. Summary of the Maxima and Minima Temperatures.

\begin{tabular}{|c|c|c|c|c|c|c|c|c|c|c|}
\hline \multirow[b]{2}{*}{$\begin{array}{l}\text { Mean Maximum } \\
\text { Mean Minimum }\end{array}$} & 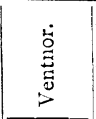 & 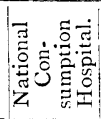 & 蒫 & 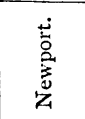 & 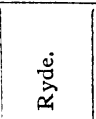 & 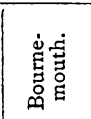 & 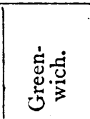 & $\stackrel{3}{3}$ & ن & \multirow{6}{*}{ 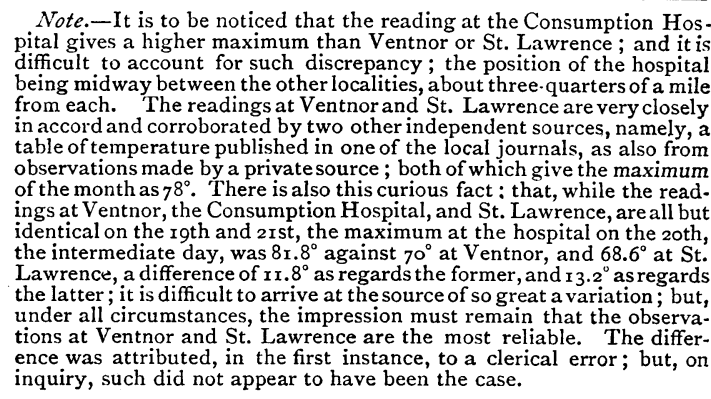 } \\
\hline & $\begin{array}{l}68.67 \\
57.16\end{array}$ & $\begin{array}{l}70.82 \\
56.04\end{array}$ & $\begin{array}{l}68.78 \\
55.87\end{array}$ & $\begin{array}{l}73.24 \\
52.72\end{array}$ & & $\begin{array}{l}73 \cdot 54 \\
53.70\end{array}$ & $\begin{array}{l}78.08 \\
54.88\end{array}$ & & $\begin{array}{l}73.25 \\
34.89\end{array}$ & \\
\hline & 2)125.83 & 2) 526.86 & 2) 124.65 & 2) 125.96 & 2) 13 3 .99 & 2) 127.24 & 2)1 132.96 & 2) 127.92 & 2) 128.14 & \\
\hline Month & 62.91 & 53.43 & $62.3^{2}$ & 62.98 & 65.99 & 63.62 & 66.48 & 63.96 & 64.07 & \\
\hline $\begin{array}{l}\text { Iaximum } \\
\text { Minimum }\end{array} \ldots \ldots$. & $\begin{array}{l}77 \\
50\end{array}$ & $\begin{array}{l}8 \mathrm{r} .9 \\
50 . \mathrm{r}\end{array}$ & $\begin{array}{l}78 \\
49\end{array}$ & $\begin{array}{r}90.4 \\
* 37.4 \\
\end{array}$ & $\begin{array}{l}85 \\
54\end{array}$ & $\begin{array}{l}83 \\
4 \mathrm{I}\end{array}$ & $\begin{array}{l}97.1 \\
43.9\end{array}$ & $\begin{array}{l}92 \\
42\end{array}$ & $\begin{array}{l}9 \mathrm{r} \\
43\end{array}$ & \\
\hline ange & 27 & $3^{1} .8$ & 29 & 53.0 & $3 \mathrm{I}$ & 42 & 53.2 & 50 & $4^{8}$ & \\
\hline
\end{tabular}

* There would appear to be some error in the minimum as returned from Newport, $37.4^{\circ}$ being at least $5^{\circ}$ too low.

TABLE III. Temperatures at Ventnor, the Consumption Hospital, and St. Lazurence.

\begin{tabular}{|c|c|c|c|c|c|c|c|c|c|c|c|c|}
\hline \multicolumn{5}{|c|}{ Ventnor. } & \multicolumn{4}{|c|}{ National Consumption Hospital. } & \multicolumn{4}{|c|}{ St. Lawrence. } \\
\hline r88o. & $\begin{array}{l}\text { Maxi- } \\
\text { mum. }\end{array}$ & $\begin{array}{l}\text { Mini- } \\
\text { mum. }\end{array}$ & $\begin{array}{c}\text { Mean } \\
\text { Maximum. }\end{array}$ & $\begin{array}{c}\text { Mean } \\
\text { Minimum. }\end{array}$ & Maximum. & Minimum. & $\begin{array}{c}\text { Mean } \\
\text { Maximum. }\end{array}$ & $\begin{array}{c}\text { Mean } \\
\text { Minimum. }\end{array}$ & Maximum. & Minimum. & $\begin{array}{c}\text { Mean } \\
\text { Maximum. }\end{array}$ & $\begin{array}{c}\text { Mean } \\
\text { Minimum. }\end{array}$ \\
\hline 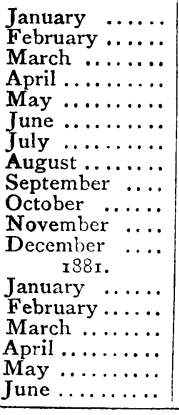 & $\begin{array}{l}51 \\
53 \\
58 \\
58 \\
72 \\
69 \\
71 \\
77 \\
76 \\
65 \\
56 \\
55\end{array}$ & $\begin{array}{l}25 \\
34 \\
36 \\
38 \\
38 \\
42 \\
51 \\
51 \\
49 \\
32 \\
30 \\
33\end{array}$ & $\begin{array}{l}40.32 \\
47.93 \\
52.54 \\
54.13 \\
61.06 \\
63.06 \\
66.48 \\
70.90 \\
66.16 \\
54.70 \\
53.46 \\
49.87\end{array}$ & $\begin{array}{l}32.80 \\
39.93 \\
42.00 \\
43.50 \\
46.51 \\
52.16 \\
56.70 \\
58.35 \\
56.83 \\
44 \cdot 74 \\
41.75 \\
42.87\end{array}$ & $\begin{array}{l}50.6 \\
52.8 \\
59.0 \\
59.0 \\
73.6 \\
68.8 \\
74.7 \\
78.4 \\
77.1 \\
66.1 \\
57 \cdot 3 \\
55.0\end{array}$ & $\begin{array}{l}24 \cdot 4 \\
32.4 \\
35 \cdot 5 \\
37 \cdot 0 \\
37 \cdot 5 \\
43.4 \\
48.4 \\
51.9 \\
47 \cdot 7 \\
32.7 \\
28.6 \\
31.8\end{array}$ & $\begin{array}{l}48.67 \\
47.79 \\
51.62 \\
54.09 \\
60.97 \\
63.18 \\
66.25 \\
70.98 \\
66.86 \\
55.68 \\
54 \cdot 36 \\
51.38\end{array}$ & $\begin{array}{l}33.44 \\
39.59 \\
41.3^{8} \\
44.79 \\
46.31 \\
50.61 \\
54.50 \\
57.95 \\
56.20 \\
44.89 \\
40.67 \\
42.17\end{array}$ & $\begin{array}{l}5 \mathbf{r} \cdot \mathbf{I} \\
53.0 \\
59.1 \\
58.6 \\
73.0 \\
67.8 \\
73.0 \\
76.6 \\
75.0 \\
65.0 \\
56.0 \\
55.0\end{array}$ & $\begin{array}{l}23.5 \\
32.5 \\
35.6 \\
36.2 \\
38.0 \\
40.0 \\
51.0 \\
52.0 \\
50.0 \\
31.3 \\
28.3 \\
32.5\end{array}$ & $\begin{array}{l}40.63 \\
47.84 \\
51.24 \\
53.67 \\
61.12 \\
62.80 \\
67.15 \\
70.61 \\
66.24 \\
55.36 \\
50.51 \\
50.19\end{array}$ & $\begin{array}{l}33.26 \\
39.03 \\
40.96 \\
43.10 \\
45.65 \\
50.56 \\
55.63 \\
57.60 \\
55.56 \\
43.68 \\
41.31 \\
42.16\end{array}$ \\
\hline
\end{tabular}


of health-resort in the United Kinglom, namely, a British climate, subject to a!l the changes and vicissitudes of weather to which it is so liable. The changes, however, are felt relatively less at the Undercliff than probably elsewhere; and the weather for the most part, if bad on the mainland, seldom visits the back of the island save in a modified form. Snow during the forty years was the marked exception, not the rule; and, during the hardest winters, not only the thermometer, but the perfect preservation of the shrubs and evergreens, bore testimony to the comparative mildness of the atmosphere. Of course, it is not pretended, favoured though it would appear to be, that it can vie with the softer and sunnier clime of the south of Europe; though the instances are by no means few, in which patients who have been from circumstances debarred from returning to the south, have done better even at the Undercliff, amidst the comforts of home, an equable temperature, and more bracing atmosphere, than they did abroad.

Now, if there is one fact which is conclusively shown by the tables which I have presented to you, it is the remarliable equability of the temperature at the back of the Isle of Wight. The range from day to day is comparatively small, both during the winter as also during the summer months, and that to a degree which I am not aware occurs in any other locality, and is one of the most striking circumstances that renders the Undercliff a desirable place, in many instances, for healthresort. The late Sir James Clark was the first to call attention to the value of the southern portion of the Isle of Wight, which he does in the following terms: "The part of the island adapted as a winter residence is that denominated Undercliff, which comprehends a tract of country, extending from Dunnose to St. Catherine's Hill, six miles in length, and from a quarter to half a mile in breadth. This singular district cunsists of a series of terraces, formed by the upper strata, composed of chalk and greensand, which have slipped down from the cliffs and hills above, and been deposited in irregular masses on the substratum of blue marl. The whole of the Undercliff, which presents in many places scenery of the greatest beauty, is dry, and free from moist and impure exhalations, and is protected from the north, northeast, north-west, and west winds, by a range of lofty downs which rise boldly from the upper termination of these terraces, leaving the Undercliff open only in a direct line to the south-east and south-west winds, which rarely blow here with great force. The climate is remarkably equable, as well as mild and dry, and there are not many days during the winter on which an invalid cannot take some exercise in the open air. The mildness of the climate may be estimated in some degree by the circumstance of myrtles, geraniums, sweet-scented verbenas, heliotropes, and other tender plants, usually withstanding the winter in the open flower-border. I have certainly seen nothing along the south coast that will bear a comparison with it." And, in a foot-note, after expressing his obligations for the assistance rendered him, he concludes with the following words: "By continuing the series of minute and careful observations on which he has already been engaged for some years, Dr. Martin will soon be enabled to fix the character of the climate of the Undercliff." So much for Sir James Clark.

Dr. Madden, in his able work on Health-Resorts of Europe and Africa, published in I876, bears likewise strong testimony to the value of the Undercliff. At page 8, speaking of climate adapted for phthisical patients, he states: "It has already been observed that these sedative climates (Torquay, Hastings, Worthing, Bournemouth) are by no means universally serviceable to phthisical patients, who more frequently require a somewhat dry, tonic, moderately warm, and bracing atmosphere. Of such climates, unfortunately, the number is extremely limited in these islands, being chiefly confined to a narrow strip, about six miles in length, situated on the south-east coast of the Isle of Vight ; i. c., the Undercliff, which undoubtedly possesses the best tonic winter climate for consumptive patients in the British Isles."

But it is to a passage in a paper published by Dr. W. Thornton Parker in the Nc:U York Medical Fournal for May 188I, "On Ventnor, Isle of Wight, and its P'eculiar Advantages for the Invalid", to which I would the more particularly direct your attention. After quoting the opinion of Dr. Simons, "That the pure air of the open sea acts in a very favourable manner, we have excellent authority; but it is not so clear that the air on sea-shores is, as a rule, salutary in its effects", he goes on to say: "Now, in the midst of all the conflicting testimony, I find that the majority seem to regard the pure air of the open sea beneficial ; it is the mixture of land and sea air which is to be feared." "The climate at almost all seaside resorts is certainly affected more or less by the mixture of land and sea-air ; but at Ventnor the air is almost, if not wholly, the pure air of the sea. No land breezes can be felt ; no streams or ponds of fresh water exist, of any considerable size. The geographical situation, far out in the ocean, the southern exposure, and the tremendous 'downs', have given to Ventnor a climate which cannot be found elsewhere, and which, I believe, considering the accessories, is unsurpassed in the world for the treatment of pulmonary disease."

Now, gentlemen, it is to be borne in mind that this is the opinion of one in every way calculated to form a just conclusion. He is a gentleman in America totally unconnected with any local interest, an able member of the profession, and one who writes, not from mere hearsay or information gleaned from books, but from his own personal experience after residing at Ventnor; and I believe, in giving the expression he has done, he has struck the key-note of any advantages which the Undercliff of the Isle of WVight possesses over other localities which have been selected as places of health-resort; and that, while at Ventnor or any other locality which the Undercliff may contain, you are not by the seaside, but actually out at sea, where you combine most of the advantages of a cruise at sea without the discomforts of a sea-voyage. The distinction drawn by Sir James Clark, and the more noticeable statement of Dr. Madden with regard to the tonic effects of the climate of the Undercliff, are attributable to that fact; and, in order to place more clearly my meaning before you, I have had a rough tracing taken from one of the ordinary maps, which may at once convey to the eye what perhaps words would scarcely so well demonstrate. You will see there the general configuration of the island, with its relative position as regards the mainland. It is to that fact, with the shelter afforded by the high ground above, and its southern exposure, that the Undercliff is mainly inclebted for its very remarkable and equable climate, its warmth in winter, and its coolness during the summer months.

In order to show the coolness of the Undercliff during the summer months, perhaps I could have had no better opportunity than that afforded by comparison with other places, during the month of July just passed. The maximum temperature, as shown by Mr. Martin at Ventnor, the Rev. Clifford Malden at St. Lawrence, with other local observers, did not exceed $78^{\circ}$.

The Undercliff is seldom, if ever, without a sea-breeze. On calm and sultry days, when there is probably hardly a breath of air on the Downs, you will generally find a light breeze eddying along the shore; and I was forcibly struck recently by the difference of temperature experienced during much of the warmer weather. On driving inland into the country, I found the heat more or less oppressive; but, directly I descended into the Undercliff, the effect of the sea breeze was immediately perceptible, and the air became comparatively cool and refreshing.

In conclusion, I cannot help referring to the very common, but somewhat vulgar error, that has deterred, and still continues to deter, many from visiting the back of the island during the summer season: it is that, as the Undercliff is comparatively warm in the winter, so it must be intensely hot during the summer; whereas the very reverse is the fact. I wish to dwell on this fact; for it is not only an injustice to the place itself, but also to those who may desire to visit it.

I have endeavoured to lay before you, as concisely as I could, some account-and, I trust, a fair and impartial account-of the climate of the Undercliff; the object, however, is, that the appended tables should speak for themselves, and the apology for producing them in the present form is the very long period over which they extend.

\section{THE ISLE OF WIGHT AS A HEALTH-RESORT.*}

\section{By JOSEPII GROVES, B.A., M.B., Carisbrooke.}

IN speaking of the Isle of Wight as a health-resort, I shall endeavour to avoid, as far as possible, any extravagance of expression arising out of that peculiar home-affection which natives of islands share with those of mountainous districts;; feeling assured I could not do the Isle of Wight a greater injustice than by exciting, by the language of exaggeration, undue expectation and consequent disappointment, or than by destroying its individuality in strained similitudes and comparisons. I shall not describe our island, therefore, as the British Madeira, or its Undercliff as the Riviera of the English Channel. We really have no Bay of Naples or Blue Grotto of Capri, though our coast is indented with several fine bays, and there are some interesting caves at Freshwater Gate. But, as a practical physician acquainted with many of the more celebrated health-resorts of the globe, I can claim for the Isle of Wight that it possesses advantages and peculiarities which account for its ancient renown and its present popularity.

The conditions which obtain in the island may be described as essentially marine on the coast, and semi-marine in the interior. Its most obvious peculiarity is, that it is an island, and the resulting general equability of temperature is its most striking possession. If I do not

* Read in the Section of Public Medicine at the Annual Meeting of the British Medical Association, held in Ryde, August 188r. 